\title{
sustainability
}

ISSN 2071-1050

www.mdpi.com/journal/sustainability

Review

\section{Monitor Soil Degradation or Triage for Soil Security? An Australian Challenge}

\author{
Andrea Koch ${ }^{1, *}$, Adrian Chappell ${ }^{2, \dagger}$, Michael Eyres ${ }^{3, \dagger}$ and Edward Scott $^{3}$ \\ 1 United States Studies Centre, University of Sydney, Institute Building, H03, Sydney \\ NSW 2006, Australia \\ 2 CSIRO Land and Water National Research Flagship, G.P.O. Box 1666, \\ Canberra ACT 2601, Australia; E-Mail: adrian.chappell@csiro.au \\ 3 Injekta Field Systems, Level 1, 69 Fullarton Road, Kent Town SA 5067, Australia; \\ E-Mails: michael@injekta.com.au (M.E.); ed@injekta.com.au (E.S.)
}

$\dagger$ These authors contributed equally to this work.

* Author to whom correspondence should be addressed; E-Mail: andrea.koch@sydney.edu.au; Tel.: +61-408-030-081, Fax: +61-2-9351-6877.

Academic Editor: Marc A. Rosen

Received: 11 March 2015 / Accepted: 9 April 2015 / Published: 24 April 2015

\begin{abstract}
The Australian National Soil Research, Development and Extension Strategy identifies soil security as a foundation for the current and future productivity and profitability of Australian agriculture. Current agricultural production is attenuated by soil degradation. Future production is highly dependent on the condition of Australian soils. Soil degradation in Australia is dominated in its areal extent by soil erosion. We reiterate the use of soil erosion as a reliable indicator of soil condition/quality and a practical measure of soil degradation. We describe three key phases of soil degradation since European settlement, and show a clear link between inappropriate agricultural practices and the resultant soil degradation. We demonstrate that modern agricultural practices have had a marked effect on reducing erosion. Current advances in agricultural soil management could lead to further stabilization and slowing of soil degradation in addition to improving productivity. However, policy complacency towards soil degradation, combined with future climate projections of increased rainfall intensity but decreased volumes, warmer temperatures and increased time in drought may once again accelerate soil degradation and susceptibility to erosion and thus limit the ability of agriculture to advance without further improving soil management practices. Monitoring soil degradation may indicate land
\end{abstract}


degradation, but we contend that monitoring will not lead to soil security. We propose the adoption of a triaging approach to soil degradation using the soil security framework, to prioritise treatment plans that engage science and agriculture to develop practices that simultaneously increase productivity and improve soil condition. This will provide a public policy platform for efficient allocation of public and private resources to secure Australia's soil resource.

Keywords: soil; soil security; agriculture; erosion; no-till; conservation agriculture; Australia

\section{Soil Security, Soil Degradation and Agriculture in Australia}

Soil security is achieved when the condition of soil enables it to support the ongoing production of food and fiber and continue its role in cycling of fresh water, climate regulation, and overall ecosystem resilience [1]. The concept of soil security emanated from deep scientific concern about global soil degradation and its impact on sustainable development. It emphasizes the critical role of soil in achieving food, water and energy security, biodiversity and climate change mitigation, and the ongoing provision of ecosystem services - all significant global challenges [2]. Soil security is necessary to achieve sustainable development and long-term agricultural productivity.

Soil is secured through agricultural land management practices that are matched to the functional capability of the soil and which improve and maintain soil condition ("Soil condition" can be used interchangeably with "soil quality" and is the official term used by the Australian Government to describe "the capacity of a soil to function, within land use and ecosystem boundaries, to sustain biological productivity, maintain environmental health, and promote plant, animal, and human health" [3,4]). This requires consideration and understanding of the five dimensions of soil security that encompass the biophysical, social and economic aspects of soil, and policy and legal frameworks that support them, i.e.:

- Capability - the potential functionality of any given soil, how it can be expected to perform and what it may produce

- Condition - the contemporary state of the soil referenced to its capability, and an outcome of how it is managed

- Capital - the economic value of the soil resource and the services that flow from it

- Connectivity - the social dimension, concerned with the connection of the land manager with their soil, and the resources and knowledge they have to manage the soil according to its capability; as well as broader societal recognition of the soil resource

- Codification - the public policy and legal frameworks required to support the securing of soil [1].

Land management practices that lead to soil degradation put soil into a state of insecurity leading to short and long term implications for sustainable development. Ultimately this may lead to the soil becoming degraded to a point that it may never return to its original state and function. In order to achieve soil security, land managers must understand the inherent economic value and biophysical 
capability and condition of their soil, have the connectedness of knowledge and resources to manage it for productivity whilst improving or maintaining its condition, and be supported by public policy that enables them to do this - encapsulating the five dimensions laid out above [1].

The Australian National Soil Research, Development and Extension Strategy (hereafter, the "Strategy") was developed through a cross-jurisdictional collaborative effort by Federal and State agencies, Commonwealth Scientific and Industrial Research Organization (CSIRO), the academic research community and industry representation through the relevant research and development corporations and farmer groups [5]. The Strategy calls for securing soil as a contribution to the current and future competitiveness of Australian agriculture and recognizes the critical need for soil knowledge, information and data to increase agricultural productivity, profitability and sustainability in Australia.

Australian farmers and policy makers have battled with soil degradation since the country was first settled. The transition from natural to agricultural land has historically been associated with the removal of natural vegetation for cultivation and grazing. However, the native vegetation had generally protected the soil from erosion by wind and water. Consequently, soil erosion accelerated where historical agriculture expanded and particularly where ploughing was used. Other soil degradation processes (e.g., acidification, salinization, loss of soil organic matter, compaction) have also increased, but globally the area affected by soil degradation is dominated by soil erosion [6].

European cropping and grazing methods were first applied across Australia at the time of settlement in the late 1700s. Agriculture and pastoral grazing then spread across the continent over the next 150 years, [7] reaching a critical mass by the early 20th century as shown in Figure 1.

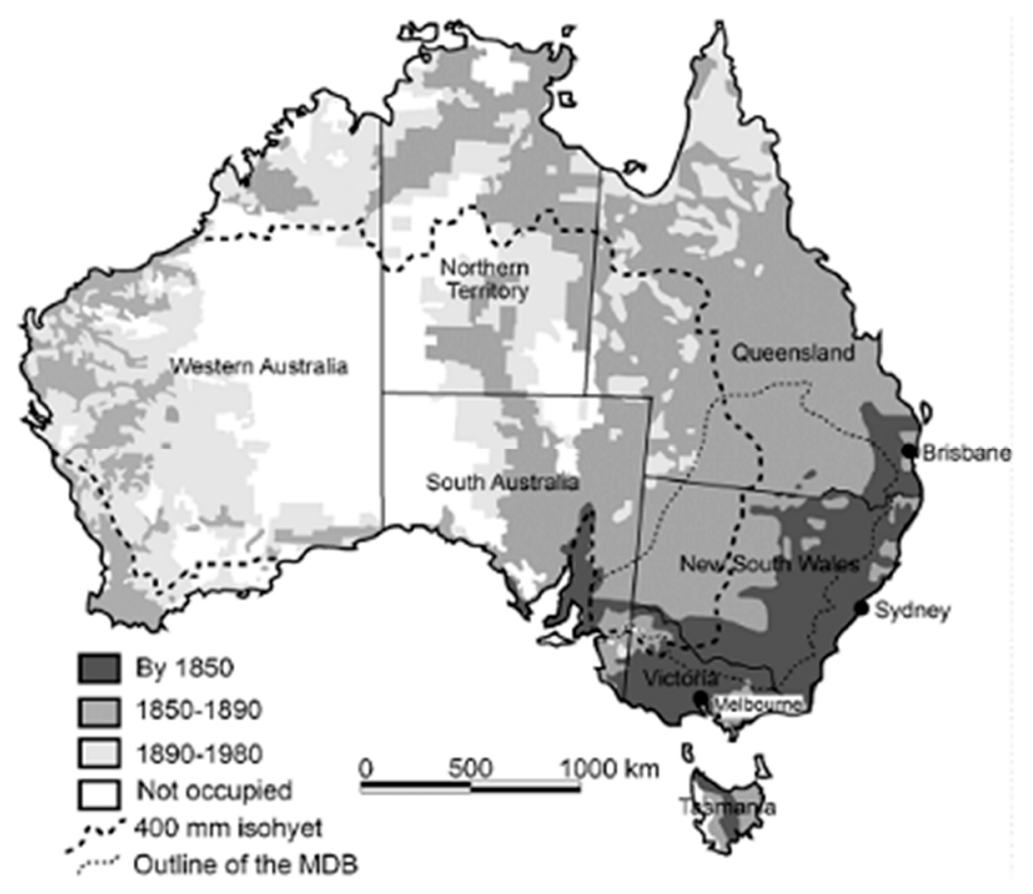

Figure 1. Pastoral development of Australia through time [8] (reproduced with permission).

Due to a fundamental lack of understanding and knowledge of Australia's old, weathered and largely infertile soil, inappropriate agricultural methods mined the soil resource with disastrous consequences. Pioneering European farmers had little context and scarce resources in an environment 
that was completely foreign to their experience. The innovation of "frontier farming" fed the growing colony and its export economy [8] but caused widespread unintended consequences. During the 1930s and 1940s, large tracts of land in Australia became "dust bowls" [9-11]. The resulting soil erosion led to significant Australian policy responses in the early 20th century and an agriculture sector that has continually sought to implement soil conservation practices [9-12]. This had led to success in reducing soil degradation over time, but as we will show, there is still much work to be done.

Soil security is a recently developed concept. Progress towards soil security can only be judged by evaluating historical efforts and outcomes of soil conservation in an agricultural context. In this paper we outline key issues of soil degradation at the continental scale in Australia within the context of agricultural land use and land management changes. We provide evidence of the relationship between soil erosion and agriculture over time, and show how adoption of conservation agriculture, specifically no-till cropping, has helped to address soil erosion in cropping systems and why conservation agriculture is a practical example of soil security. We continue by showing that despite the gains, this has not solved erosion in current cropping systems and outline a range of impacts on soil condition as a result of no-till. We contend that the next step-change in cropping should be based on analysis of soil at the paddock level. This will lead to agricultural practices that provide the win-win of increased productivity and improved soil condition — both key requirements for soil security. Finally, we return to the continental scale to suggest that complacency towards soil erosion will greatly impact Australia's broader ability to secure soil and increase food production. We contend that monitoring the continued degradation of Australia's soil will not lead to soil security. Instead, we propose the adoption of a triaging approach to soil degradation that is based on current science and improved agricultural practices supported by appropriate public policy to ensure that public and private sector resources are applied appropriately and rapidly to safeguard the nation's soil resources.

\section{Australian Land Use and Soil Degradation}

It is important to understand some key aspects of Australian agriculture to contextualize historical and contemporary soil degradation patterns. Just over half (52 percent) of Australia is used for agriculture. Of that, 86 percent (340 million hectares) is used predominantly for grazing and about eight percent (32 million hectares) is used mainly for cropping [13] (Figure 2).

Agriculture is mainly located in the south-eastern and south-western regions of Australia, with the remaining 81 percent of land consisting of rangeland i.e., native vegetation with erratic and/or small rainfall that precludes agriculture [14].

Pastoralism is the main agricultural pursuit in the rangelands. Australia's economic growth "rode on the sheep's back" due to heavy grazing by sheep for wool and meat in the rangelands and agricultural areas during early settlement and through to the 20th century [8]. Today, rangeland livestock is predominantly beef cattle. This contemporary land use pattern may be set to change, with a Federal Government plan for significant development of northern Australia including large new irrigation/dam projects for agriculture [15]. New trade agreements with Asian nations will increase opportunities for significant increases in livestock production. This has potential implications for soil security in the north, which has been and continues to be impacted by soil degradation [16]. 


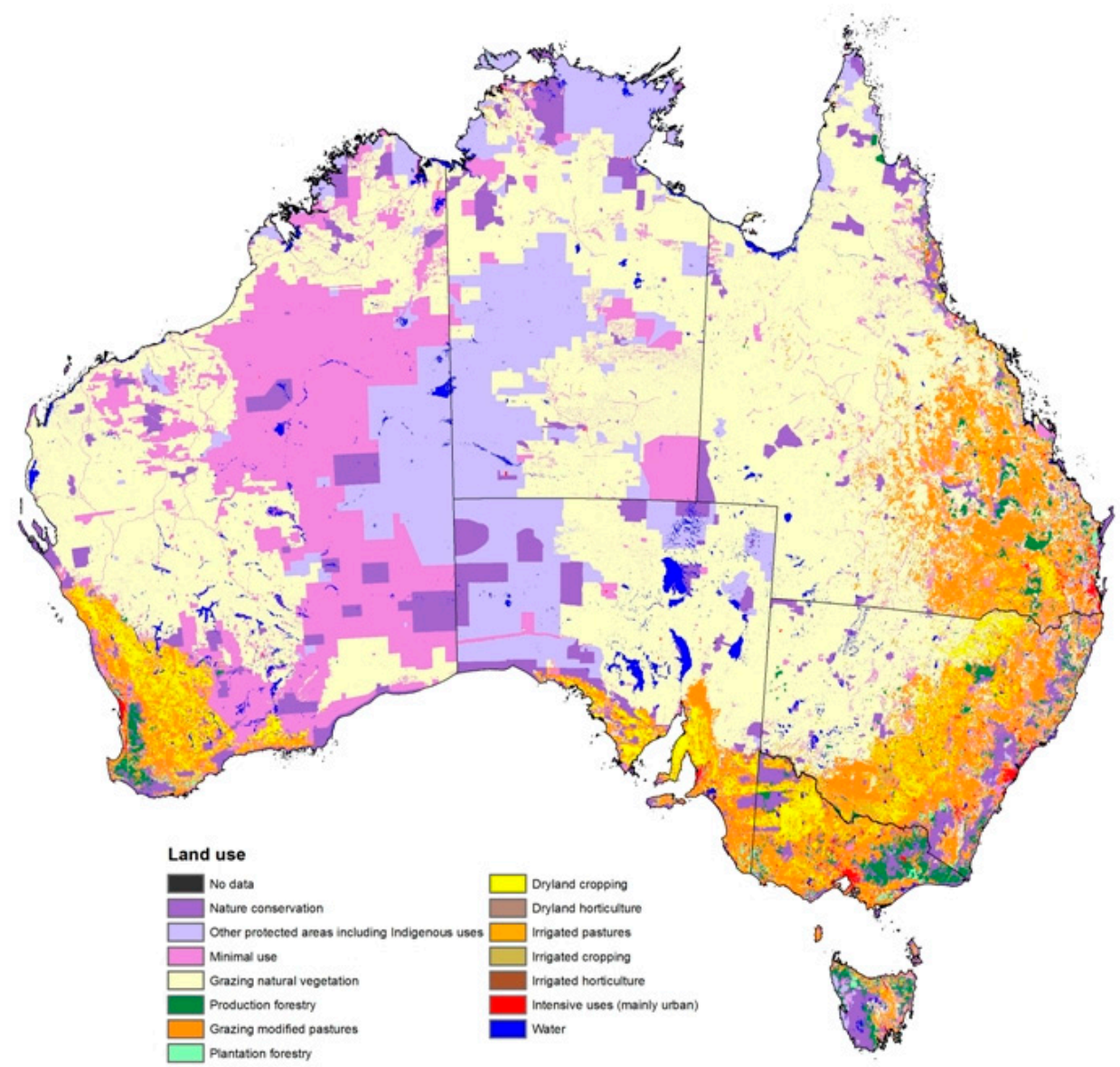

Figure 2. Land use of Australia for 2005-2006, national scale land use map developed by ABARES in 2010. Source: Australian Bureau of Agricultural and Resource Economics and Sciences [17].

At the continental scale, soil degradation in Australia is broadly characterized by four processes; soil acidification, soil carbon loss, water and wind erosion [16,18]. These processes are used to indicate the status of the soil or its condition. Policy focus on these processes is driven from economic and environmental considerations.

Soil acidification is estimated to affect over 50 percent of cropping and/or intensively grazed regions, with soil acidity in many agricultural regions continuing to deteriorate [16]. The Western Australian Government estimates that soil acidity is already impacting state farm gate returns to the tune of $\$ 400$ million per annum through lost production. This region produces half of Australia's wheat (Triticum aestivum L.) crop and supplies 80 percent of the wheat exports [19].

Australian agricultural soil has lost between 40 and 60 percent of its soil carbon content since settlement [20]. Soil carbon dynamics have received much attention over recent years as governments have considered the potential of soil carbon sequestration as carbon sink in climate change policy. Prior to this, increasing soil organic carbon (SOC) was a key program focus for State based Catchment Management Authorities and Natural Resource Management agencies across the country, in efforts to improve soil condition. Community based programs administered through Landcare and the Federal Caring for Country program have also provided focus for improving SOC [21]. 
It is estimated that water erosion is now outstripping soil formation rates across Australia by a factor of several hundred and in some areas, several thousand [16]. There is a dearth of measured water erosion data across continental Australia, but a modeling study in 2003 predicted sheetwash and rill erosion rates for the entire Australian continent using the revised universal soil loss equation (RUSLE) and spatial data layers that provided a range of environmental factors [22]. The study concluded that northern Australia is at higher risk for water erosion than the south and that there is significant seasonal variation between summer and winter. It estimated the average erosion rate to be $4.1 \mathrm{ton} / \mathrm{ha} / \mathrm{year}$ across the continent, and that about $2.9 \times 10^{9}$ tonnes of soil is moved annually, representing 3.9 per cent of global soil erosion from 5 per cent of world land area [22]. One of the limitations of using the RUSLE model within the context of commenting on soil erosion by all processes is the inability to account for deposition and wind erosion.

As we show later, the prevalence and severity of wind erosion has subsided since the "dust bowl" years of the late 19th and early 20th centuries, however the strongest determinant of wind erosion may be climate [16]. Climate change in Australia is expected to result in more extreme wind and flooding events. Both have been experienced across the continent during the past decade and anecdotally caused significant dust storms and soil loss through water erosion [16].

The issue of soil degradation by erosion is compounded by the selective nature of the removal processes and therefore the type of material that is removed. This is particularly important for soil organic carbon, which is critical for soil aggregation, moisture holding and feedback processes for soil fertility. Consequently, preferential removal of SOC by erosion increases susceptibility of the soil to further erosion and depletion of soil nutrients.

Overall, these continental scale indicators have considerably different spatial and temporal frequencies; they may be discrete in some areas and overlap in other areas and likely have interactions that stem from a common cause (i.e., soil erosion). In any case, soil erosion dominates in areal extent. The complement of water and wind erosion covers the majority of the Australian continent.

Soil erosion has and continues to impact agriculture, but it has lost focus as an issue. Constitutionally, soil conservation is the responsibility of State Governments in Australia, and while many States have long term legislation aimed at reducing soil erosion, over recent decades there has been a gradual decline in the resources invested to address soil degradation including erosion, compared with competing natural resource management issues [21]. Should this trend continue, Australian soil in many areas will become increasingly insecure.

Erosion is the highest existential threat to soil, and the biggest risk to achieving soil security. In the next section, we describe soil erosion over time to show how it continues to be the primary soil degradation issue at the continental scale. By mitigating soil erosion, many other forms of soil degradation can also be alleviated. For example, soil erosion by wind and water is partly responsible for the loss of soil organic carbon. Similarly, the loss of topsoil and/or the preferential loss of nutrientand carbon-rich fines may have aggravated the acidification process. We also show that strategies to address soil erosion in cropping systems have produced unintended changes in soil conditions (such as stratification of nutrients, herbicide accumulation, compaction, localized acidity, and aluminum toxicity) that are causing paddock scale issues for soil management. 


\section{Soil Erosion in Australia-A Historical Snap Shot}

\subsection{Soil Erosion Rates by Land Use-1950s to 1990s}

For a single point within the landscape, the ${ }^{137} \mathrm{Cs}$ technique provides a reliable retrospective estimate of net (time-integrated) soil redistribution (erosion and deposition) due to the combined effect of wind, water and tillage. The ${ }^{137} \mathrm{Cs}$ technique has been used to estimate soil erosion in studies around Australia since the 1980 's. In the early 1990 's a national survey of ${ }^{137} \mathrm{Cs}$-derived net $(1950-1990)$ soil redistribution from transects across all states in Australia showed that soil losses were significantly greater under conditions of intensive agriculture and on rangelands compared with uncultivated pasture and forest [23]. These differences were attributed to soil disturbance, lack of ground cover and susceptibility to water and wind erosion (erosivity and erodibility). Sixty per cent of sites had net soil losses greater than 1 tonne per hectare per annum; well above the tolerable soil loss threshold of 0.5 tonnes per hectare per annum followed by Loughran et al. [23]. This analysis showed that despite significant landholder awareness of erosion events, serious unsustainable soil losses had occurred throughout much of Australia between the mid-1950s and 1990. Further analysis of these data by Chappell et al. [24,25] showed that nearly five times more soil was lost from cultivated land than from uncultivated land in Australia over that period (Figure 3).

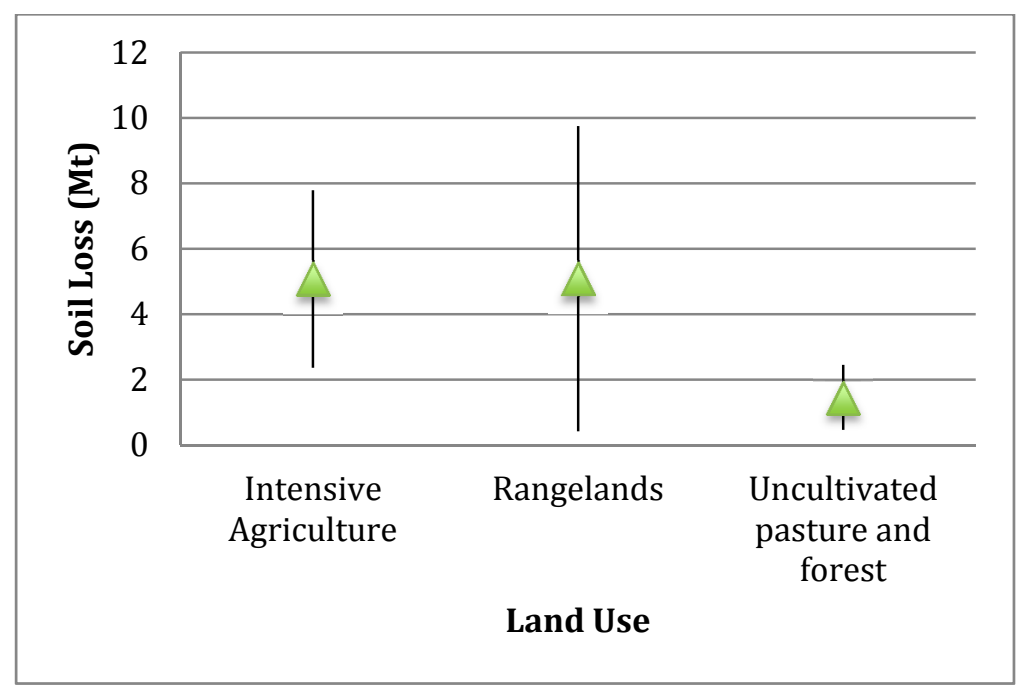

Figure 3. Comparative soil loss (1950s-1990) by land use.

\subsection{0s to Present-Changing Cropping Practices and the Impact on Soil Erosion on Agricultural Land}

Many Australian grain farmers are now well versed in the nature and benefits of conservation tillage, i.e., seeding with no prior cultivation [12]. Stubble management, and more recently, "retained stubble" management has had marked influence on soil erosion [26] by increasing surface roughness, reducing near surface wind speed by up to 80 percent [27] and controlling mechanical dispersion and structural degradation due to rainfall impact and surface water run-off [28]. 
From the 1980s onwards, there was rapid and widespread adoption of conservation tillage practices. The adoption rates for no-till practices across the grain growing areas of south-eastern and south-western Australia are summarized in Figure 4 [29].

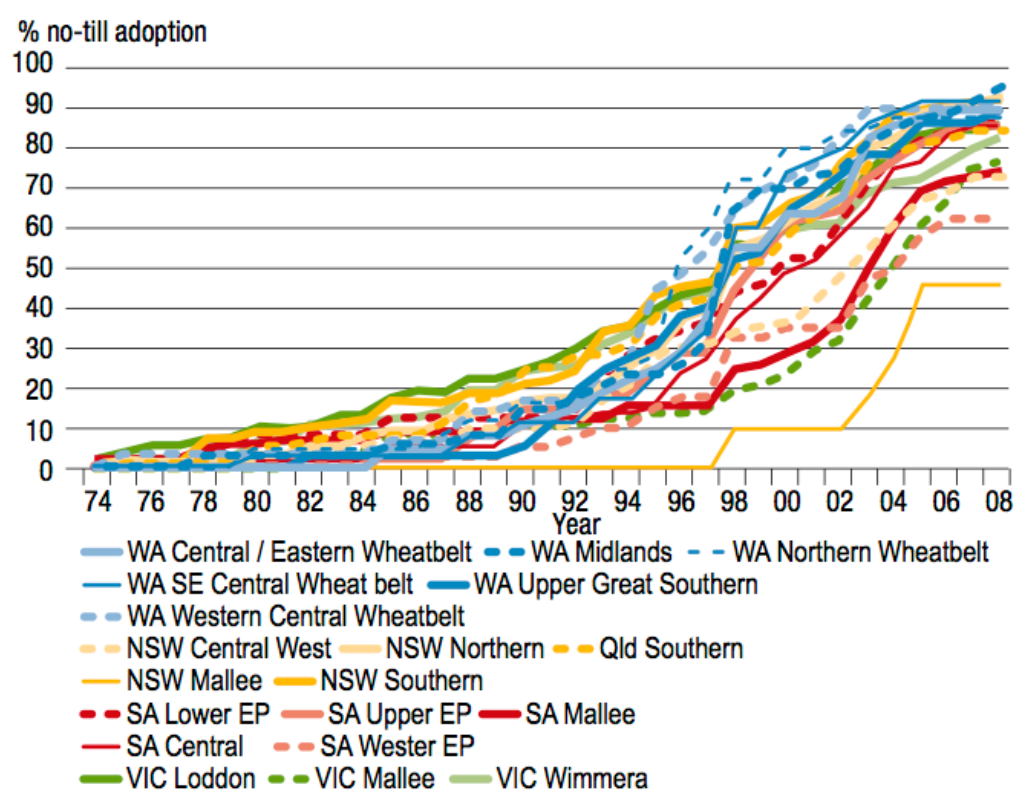

Figure 4. Cumulative adoption of no-till (decision to first use no-till) across Australian cropping areas [29].

There is evidence to suggest that the wide-scale adoption of no-till and other conservation agriculture practices has had a marked effect in reducing soil erosion in the cropping zones. For example, net (1990-2010) soil erosion in south-eastern agricultural Australia erosion had declined on average (Figure 5) from -9.7 ton/ha/year to +3.9 ton/ha/year [30].

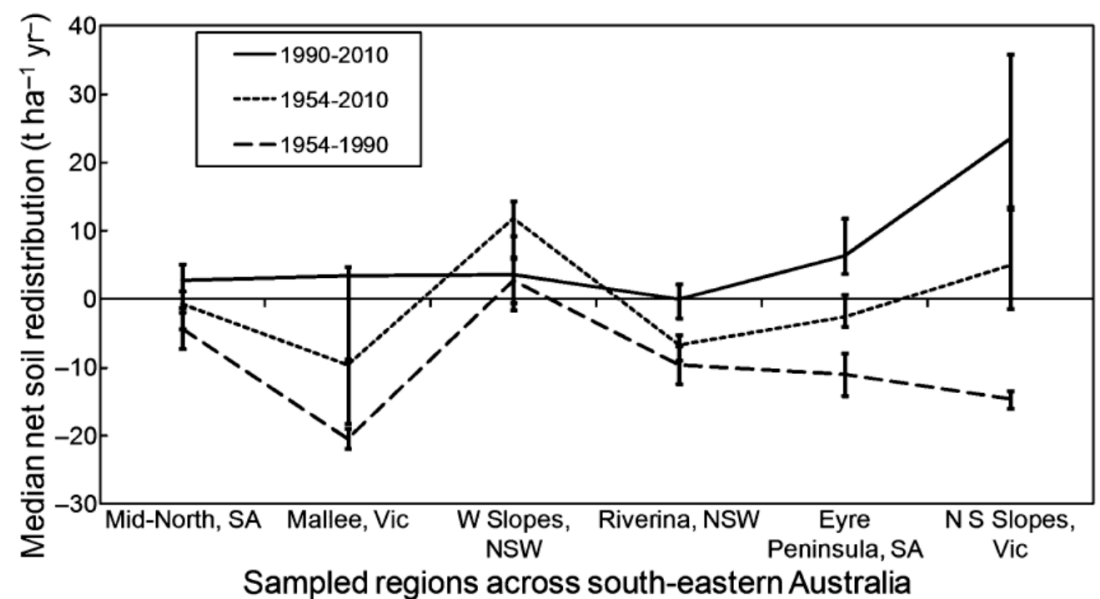

Figure 5. Change in soil redistribution median and interquartile range for south-eastern Australia (1954-2010) [30].

The regional decline in soil erosion was attributed to the widespread adoption of soil conservation measures and in particular conservation agriculture over the last 30 years. Notably this average decline 
included considerable spatial variation with an interquartile range of -1.6 to +10.7 ton/ha/year, likely due to variability in the adoption of conservation agriculture.

A study by Marx et al. [31] also indicates the success and efficacy of conservation agriculture in reducing wind erosion since the 1990s. Using dust deposited in a Snowy Mountains mire, they reconstructed the wind erosion history and the expansion of dust sources associated with the progression of European farming practices across south-eastern Australia (Figure 6). They identified a rapid increase in dust deposition after 1879 (B) and a rapid decrease in dust deposition after $1989(\mathrm{H})$. Three phases of dust deposition were defined, which they described as: (1) pre-European 1700-1879; (2) agricultural expansion 1880-1989; and (3) agricultural stabilization 1990 to 2006.

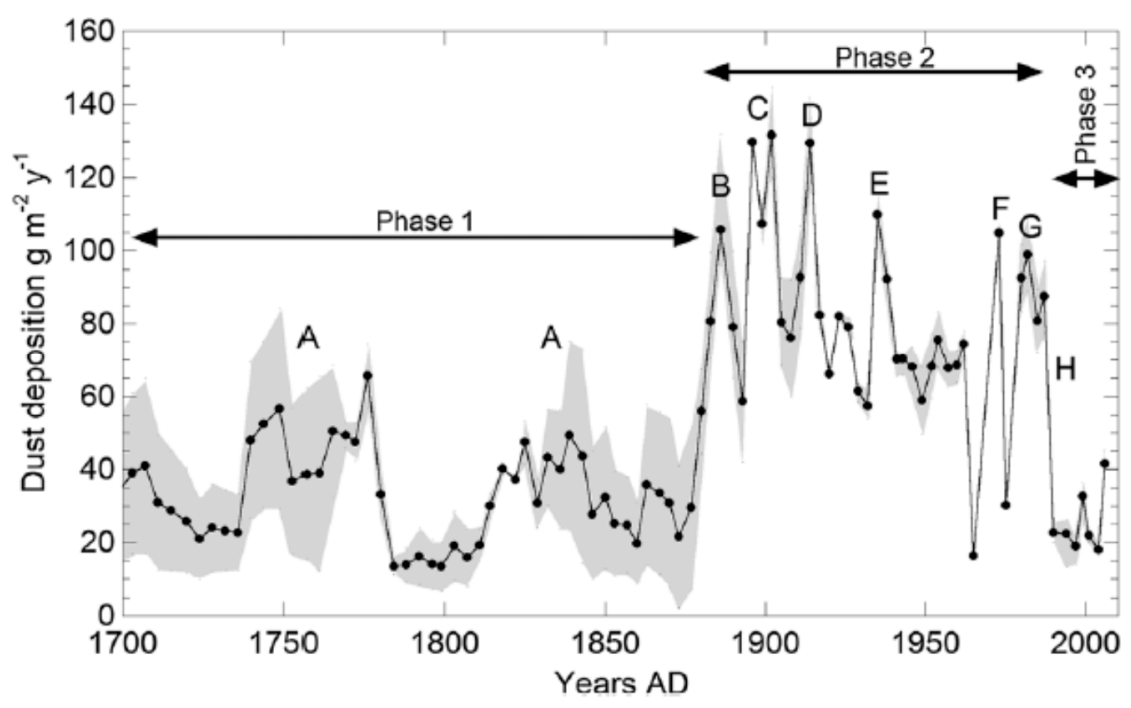

Figure 6. Dust deposition rates in the Snowy Mountains based on core data plotted from 1700 to 2006 [31]. Reproduced with permission.

The widespread adoption of no-till and conservation agriculture and the resulting reduction in soil erosion provides a case study in the practical application of soil security. Research into the uptake of no-till as shown in Figure 4, also found that farmers were motivated mostly by the reduction of fuel and labour costs, and soil conservation including soil moisture management and improved soil structure [29]. This indicates an awareness of the biophysical capability and condition issues of soil by farmers, and a desire to improve the situation. Further to this, there was a perceived increase in capital value of the soil. Consequently half of the surveyed farmers indicated they would be willing to pay more for neighbouring land that been cropped under no-till and conservation agriculture [29]. Further analysis of this case study framed by the five dimensions of soil security may inform future planning to develop approaches that secure soil.

\section{Soil Security Issues Stemming from Success}

The successful reduction of soil erosion in some Australian cropping systems is well acknowledged. There are two arising issues that we now address. The first is concerned with the codification (policy) dimension of soil security, the second with the connectivity dimension. 


\subsection{False Belief that Erosion has been Solved}

First, the success in reducing soil erosion through such a widespread practice change has led to a belief in some quarters that soil erosion is no longer a major problem for farmers. As a result, State Government programs to address soil erosion have been scaled back over recent decades [21]. This has led to a level of confidence that soil erosion has been addressed, but erosion levels are still above tolerable and regenerative limits and will continue to impact agriculture, particularly under a changing climate, unless preventing further soil erosion remains a focus.

At a tolerable loss rate of 0.5 tonnes per hectare per annum [23], 55\% of Australia could be considered net stable but many areas, particularly in agricultural Australia, are at a considerable risk (e.g., 70\% chance) of exceeding that threshold [25]. With the anticipated development of agriculture in northern Australia it is important to quantify soil erosion and respond quickly to any deterioration in the soil resource. Figure 7 shows the probability of soil erosion exceeding the threshold at different locations across Australia. Large areas of Australia were at risk in 1990 and the most susceptible areas to soil erosion were the main agricultural regions of Australia.

Conservation tillage has likely gone part way to reducing intolerable levels of soil erosion in cropping areas, but soil erosion has not been eradicated. Estimates that show a regional decline in soil erosion between 1990 and 2010 also show considerable spatial variability, indicating that many sampled locations have not reduced soil erosion, most notably in the Mallee region (see case study below). Continued policy complacency towards this trend may lead to reduced agricultural productivity and sustainability.

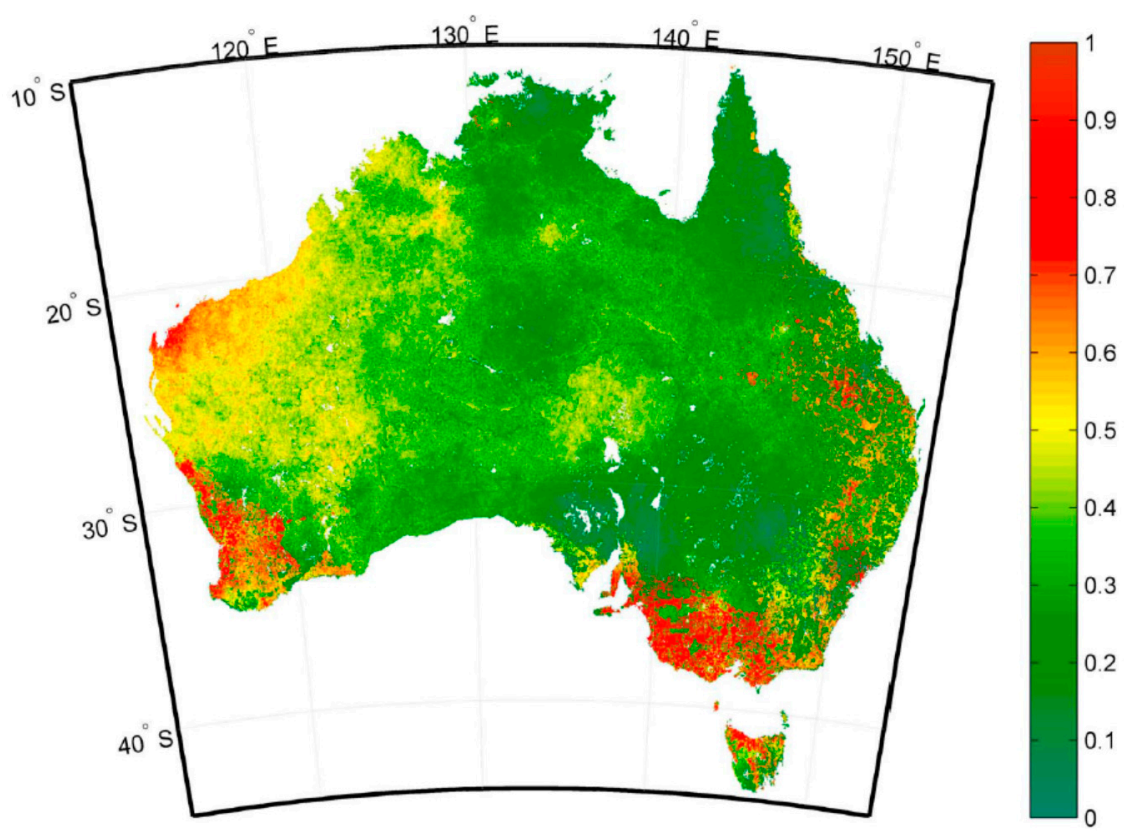

Figure 7. Probability (0-1) of exceeding the threshold -0.5 ton $\mathrm{ha}^{-1}$ year $^{-1}$ of tolerable soil erosion [25]. Reproduced with permission. 


\subsection{Unintended Consequences of Conservation Tillage}

A second issue associated with the perceived success in controlling soil erosion is that evidence has emerged that conservation tillage is producing unintended consequences for soil resources at the paddock/field level. This includes the physical and chemical restructuring of the soil profile, leading to new constraints for plant growth and crop yield. But perhaps a greater threat is the declining connectivity of farmers with the soil they manage, resulting in a lack of focus on soil and complacency towards soil management, leading to a "blind spot" in the land management toolkit.

With conservation tillage, soil is often cultivated (and fractured) to a depth greater than with conventional tillage systems; many tillage passes are used to work the soil more vigorously but to a shallower depth. This is certainly the case with knife-edged tillage which uses tractors with far more horsepower (and weight) per tyne than ever before. This deeper tillage can lead to soil disturbance and compaction [28], and may produce either positive or negative consequences depending on the soil type and condition. Conservation tillage machinery provides a well-engineered set of instruments that successfully achieve the outcome they were designed to achieve-causing minimal surface soil disturbance whilst maintaining a suitable seedbed for seed planting and growth. However limitations arise when the soil capability is not well understood and soil condition is not further managed to accommodate the new tillage strategy. Due to the reduced physical intervention with the surface soil compared to conventional tillage systems, more emphasis is placed on the inherent soil chemical, physical and biological condition and how it can support the given management system. For example soil compaction is often generally attributed to vehicular or animal traffic, however certain soil types are more susceptible to this type of decline in condition and resilience. This places those soil resources at a higher risk for this form of degradation.

There is also evidence of the stratification of soil layers due to conservation tillage, with an unintended effect of more defined nutrient distributions within the various soil layers [26]. This stratification is leading to layers of altered soil chemical condition down through the profile in duplex, texture contrast soil types or even homogeneous soil textures. Other problems include acidification, alkalization, salinity and sodicity. This altered soil chemistry can directly impact the potential for above and below ground crop performance and lead to greater risk of land degradation in the post crop phase. For an example, see the Victoria Mallee Case Study below.

Case Study 1. Victorian Mallee

The Mallee region in south-western Victoria is at high risk of wind erosion due to the removal of native vegetation and its replacement with agricultural ground cover, which is often below 50\% [32]. The region also has a sandy soil type (relict aeolian dune-swale landforms) and small mean annual rainfall $(270-370 \mathrm{~mm})$. The dune-swales are often duplex soils with sandy textured topsoil over a dispersive medium clay. At a typical study site in this region, wind erosion was compounded by water erosion during rare high intensity rainfall in the summer of December 2011. Despite the use of stubble retention water erosion removed the sandy topsoil and revealed the sub surface effect of conservation tillage equipment tines (Figure 8). The site also had a sealing, dispersive subsoil with low soil porosity (i.e., smaller hydraulic conductivity than the topsoil), degraded soil structure and poor root penetration 
despite the shallow subsoil depth. This case study demonstrates the impact of conservation tillage on soil structure and the lack of understanding of the complexity of agricultural soil profiles.

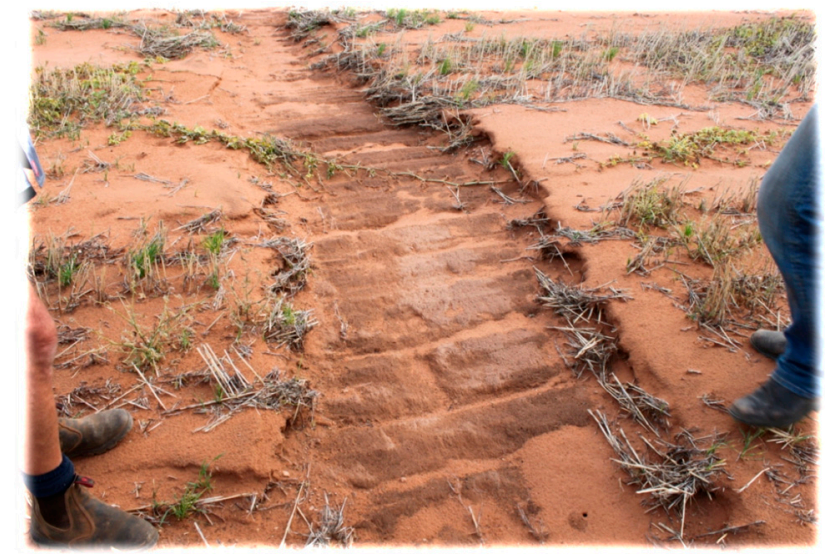

Figure 8. Rill Erosion in no-till cropping system after extensive and intensive rainfall event. Evidence of striations in clay subsoil from no-till machinery sealing the dispersive clay subsoil. Manangatang Vic.

These problems described above can be managed effectively if the farmer is aware of them. The adoption of conservation tillage has led to Australian agricultural management systems that are managed from the "top-down" due to a focus on plant breeding and growing plants that are more suited to the conservation tillage. Consequently, there is less focus on the "bottom-up" specific soil constraints that prevent plants from successfully performing in the soil environment. Prior to no-till and chemical farming, land managers had to understand their soils to greater depth and detail to implement effective weed management, improve plant germination and early growth, and achieve effective soil moisture management without chemical intervention [33].

Although gaining improved outcomes in reducing soil erosion and improving productivity, the new approach has reduced the previously close connection between farmers and the soil they manage.

Today, land managers have the most influence on soil performance at one critical point in the season (at planting). From then on the crop management relies heavily on the extensive use of chemicals [34]. This system leads to greater reliance on plant information as a guide for future performance with little focus on soil condition and performance for more effective farm management strategies. Achieving the win-win of increased productivity and reduced soil degradation in cropping lands is possible, but only with a greater agronomic understanding of the soil throughout the profile in order to optimize conservation tillage practices. Soil is more likely to be investigated in the top $10-15 \mathrm{~cm}$ but there is much to be gained by understanding the subsoil horizons and their often marked impact on plant performance.

\section{Soil Management for Improved Productivity and Soil Security in Cropping Systems}

Some farmers are now reconnecting with the soil and embracing soil management as the basis for agricultural production and as a key indicator to land management performance [35]. Soil Use Efficiency (SUE) is a diagnostic and management tool that is being used as part of this approach. 
Assessments of SUE use individual and inter-related factors (inherent and dynamic) affecting soil condition (i.e., chemical, physical and biological soil properties and processes as well as soil nutrient availability and nutrient uptake potential) as effective reference points for improving crop productivity on individual and varying soil types. SUE is effectively an interpretation of soil condition and land suitability to generate field information powerful enough to affect net farm productivity. SUE is the practical application of soil capability and condition, the two biophysical dimensions of soil security.

Water Use Efficiency (WUE) and Nutrient Use Efficiency (NUE) guidelines are being adopted, but these strategies provide measurements as an output and include too few management guidelines to further improve land management systems. Optimization of WUE and NUE requires an understanding of the boundary conditions of SUE. This will enable Australian agriculture to progress and help farmers utilize conservation tillage practices to their full capacity by renewing the focus on the fundamental underlying agricultural performance factor - the soil, and the individual components of site-specific soil management.

The starting point for understanding and implementing SUE is the excavation of soils to depth in paddocks to gain an understanding of how plants are interacting with soils throughout the soil profile, and to identify any constraints that the soil profile is placing on plant growth. This is augmented with detailed and extensive soil physical and chemical assessments to provide details of chemical constraints such as acidity, sodicity, alkalinity, or elemental toxicity. Collectively, these assessments provide the farmer with a clear understanding of what is happening in relation to soil performance.

Once this soil analysis is complete further site-specific actions can be implemented within the furrow. The best intervention point for plant production is with the usage of tillage implements when sowing. Sowing equipment can be used to tailor the application of inputs suitable to both soil type and condition for optimum plant performance based on soil capability and condition. The approach replaces the current "plants down" approach to soil management (i.e., soil adaptability) with a "soil-up" approach that is key to increasing agricultural productivity. This can be referred to as soil management based agriculture.

Many cropping systems are utilizing variable rate nutrient applications (nitrogen and phosphorus) applied across the landscape according to soil types, which doesn't necessarily account or allow for the condition of the soil throughout the profile. When conservation tillage practices are combined with the SUE approach, a Vertical Rate guideline can be established. This effectively incorporates the impact of the individual soil horizons on plant accessible water and nutrients (including oxygen and carbon dioxide).

SUE and Vertical Rate guidelines are already being utilized in management strategies. For example in addressing the key issues of soil acidification (which can often be caused by aluminium hydrolysis), utilization of strategic lime applications and the integration of furrow applied high $\mathrm{pH}$ calcium based liquid soil conditioners offset the impact of aluminium toxicity and localize the increase of $\mathrm{pH}$ in the root zone to support the growth of juvenile plants. Deep banding of manures, composts, lime and gypsum has also been integrated in to some cropping systems, leading to improvement in the subsoil condition by reducing the constraints of poor soil structure, sodicity, salinity, or other issues.

Crop rotation is also a widely utilized mechanism of soil management to depth. By rotating cereals, brassicas, legumes and pasture, the soil is given capacity to respond and recover from intensive cropping systems. Due to varying root morphology and architecture the utilization of the soil profile 
can vary. Plants with tap root systems provide biopores that are capitalized on by future crops and water infiltration processes. These approaches are being proven on a case-by-case basis to reduce soil erosion and to increase agricultural productivity — a soil security "win-win". An example is provided in the South Australian Case Study below.

Case Study 2. South Australian Mallee-Soil Use Efficiency at Work

In the South Australian Mallee the evidence of soil management and its impact on the landscape is severe. Figure 9 shows the impact of wind erosion after a prior "conservation tillage" crop despite stubble retention. Plant density was poor and wind erosion caused soil loss over the summer periods. The sandy soil is hydrophobic - water repellent - and the infiltration of water into the soil profile is slow and non-uniform, impacting seed germination and plant density. In the following planting season, the land manager has strategically ploughed the surrounding dune area to reinstate the crest of the dune. Hydrophilic sand was redistributed across the surface and integrated with the hydrophobic sand. At the following planting, wetting agents and biodegradable surfactants were used to reduce the hydrophobic properties of the soil. A comprehensive fertility programme was delivered to the seed in furrow with a liquid delivery system at planting. A top-dressing program was also implemented throughout the season. This resulted in a greater germination and plant density on the area, leading to greater soil stabilisation and retention of topsoil in the following summer period (Figure 10).

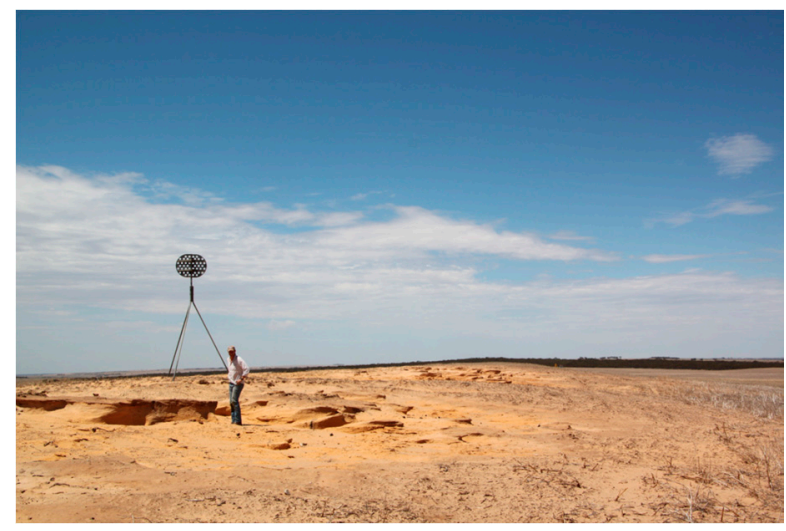

Figure 9. Evidence of wind erosion at trig point near Bow Hill, South Australia, 6 February 2013, in a continuous No-Till cropping system in a dune swale system.

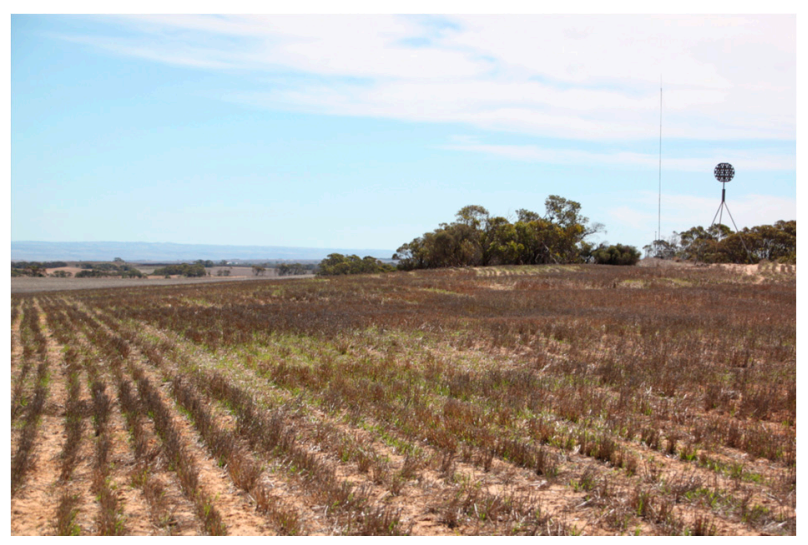

Figure 10. Impact of stubble retention and improved management practices on soil stabilization at the same site from Eastern end. 26 February 2014. 


\section{Soil Erosion Still Remains a Major Threat to Soil Security}

Despite the advances in reducing soil erosion in cropping systems, soil erosion remains a major problem in Australia and in particular in the rangelands and is a major threat to future soil security. A well-established dust emission model was used to show that between 2000 and 2011 mean dust $(<22 \mu \mathrm{m})$ emission was $1.34 \mathrm{TgC} /$ year and $0.11 \mathrm{TgC} /$ year for rangeland and agricultural Australia, respectively [36]. Despite smaller SOC dust emission and SOC contents than agricultural Australia, the largest loss of SOC dust emission is from rangeland Australia because of the large area affected by wind erosion and dust emission. Using net soil erosion for rangeland Australia ( -0.22 ton/ha/year) and the area of rangeland (666 Mha), the net total amount of soil removed was $147 \mathrm{Mt} /$ year. Using net soil erosion for agricultural Australia ( $-1.48 \mathrm{ton} / \mathrm{ha} / \mathrm{year}$ ) and the area of agricultural land (53.6 Mha) affected by soil redistribution, the net total amount of soil removed was $79 \mathrm{Mt} /$ year (Figure 11).

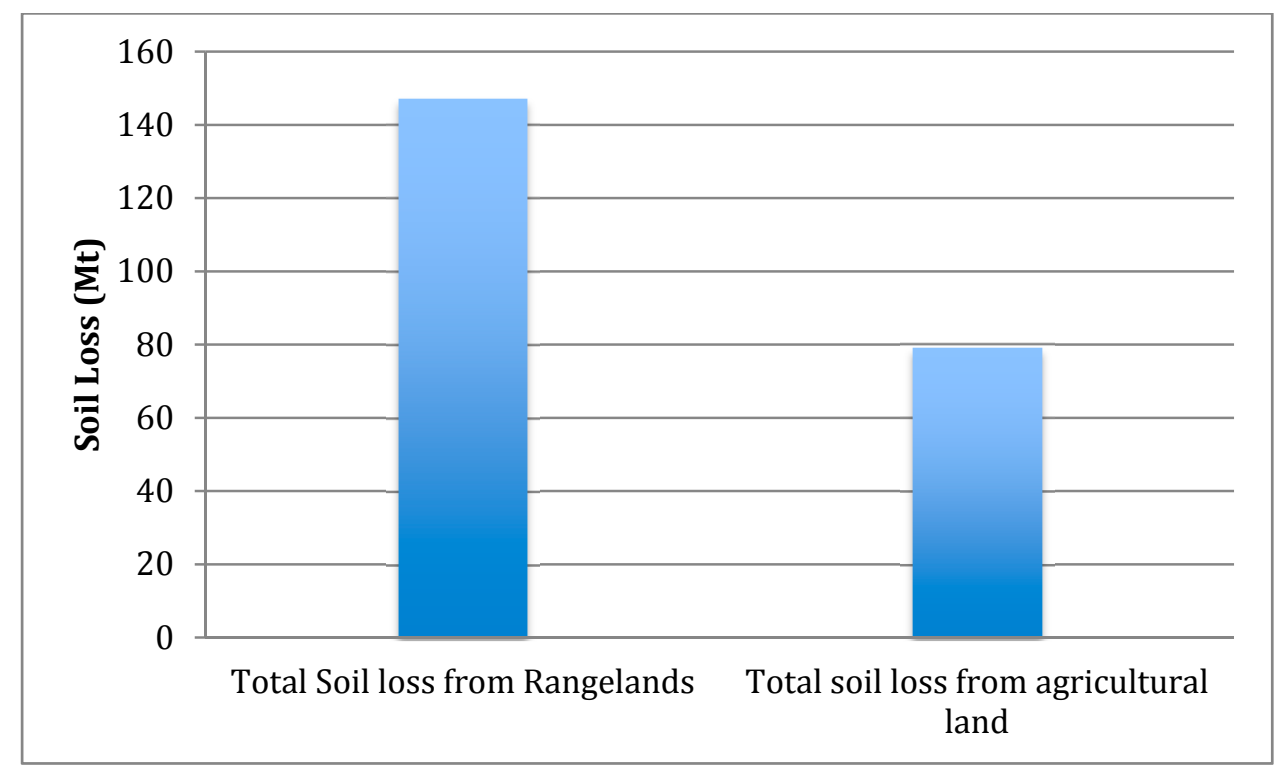

Figure 11. Soil loss by land use 2000-2011.

This indicates that despite smaller erosion rates in rangelands, their large area contributes more to the net loss of soil across the continent than the larger erosion rates from agricultural regions. The sum of $226 \mathrm{Mt} /$ year (226 Tg/year or $0.23 \mathrm{Pg} /$ year) is broadly consistent with the global regional estimates of gross water and tillage erosion from croplands and pasture in Australia [37]. Estimates of ${ }^{137} \mathrm{Cs}$-derived net (1950's-1990) soil redistribution by wind, water and tillage from rangeland and agricultural Australia amount to about $3 \%$ and $<1 \%$, respectively of the global total [25] removing approximately $2 \%$ of the total SOC stock $(0-10 \mathrm{~cm})$ from the land surface over this ca 40 -year period [38].

Policy for cropping land introduced in the 1980s makes a clear linkage between changed agricultural practice and soil conservation, and has been successful due to widespread implementation by farmers and as outlined previously, provides a useful case study of the practical application of the soil security framework. Unfortunately there has been no such effective counterpart in rangelands. Soil erosion in rangelands appears to be set to continue and potentially accelerate under a changing climate. There is also evidence that abnormal climate events can still have devastating effects on soil. The following two case studies illustrate the impact of unusual but extreme wind and flooding events. This 
suggests that for small magnitude, large frequency climate events conservation agriculture may be coping. However, large magnitude, small frequency climate events demonstrate how marginal the protection is against wind and water erosion, particularly in rangelands, where wide-scale adoption of management strategies that secure soil is yet to happen.

\section{Case Study 3. Red Dawn}

The dust storm on 22-23 September 2009, dubbed by the Press as "Red Dawn", was the largest recorded in 50 years and caused the largest reduction of visibility ever recorded in Sydney (Figure 12). The cause was attributed to extensive drought conditions and extreme winds [39]. The sources of the dust were the lower Lake Eyre Basin in South Australia, the grazing lands of north-western NSW and the mining areas around Cobar and Broken Hill in addition to the Channel Country of Queensland [39]—all rangeland areas.

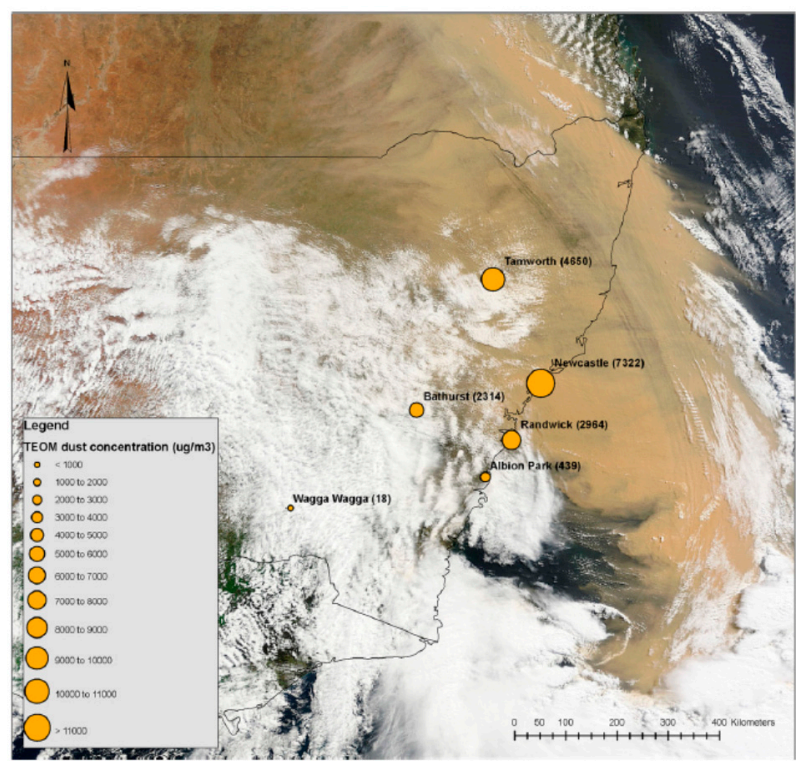

Figure 12. MODIS image showing "Red Dawn" dust storm extending from south of Sydney to NSW border with Queensland [39]. Reproduced with permission.

The economic impact of Red Dawn to the state of New South Wales was estimated to be A \$299 million, compared with a conservative estimate of the annual average cost to Australia of dust storms of A $\$ 9$ million [40].

Case Study 4. The Gascoyne Flood, 2010 and 2011

The Gascoyne River catchment covers an area of about $80,400 \mathrm{~km}$ in the southern rangelands of Western Australia. The town of Carnarvon is located at the mouth of the river, along with about 1000 hectares of irrigated horticulture. The catchment supports an extensive pastoral industry mainly grazing beef cattle (although historically, predominantly sheep) [41].

Widespread and extreme floods occurred during the period December 2010 and during the summer of 2010-2011, causing an estimated A $\$ 90$ million in damage to the horticulture industry. Soil loss through water erosion was estimated to have been at least 5,625,000 tonnes - the plume of red soil into the ocean was visible from space [41] (Figure 13). 


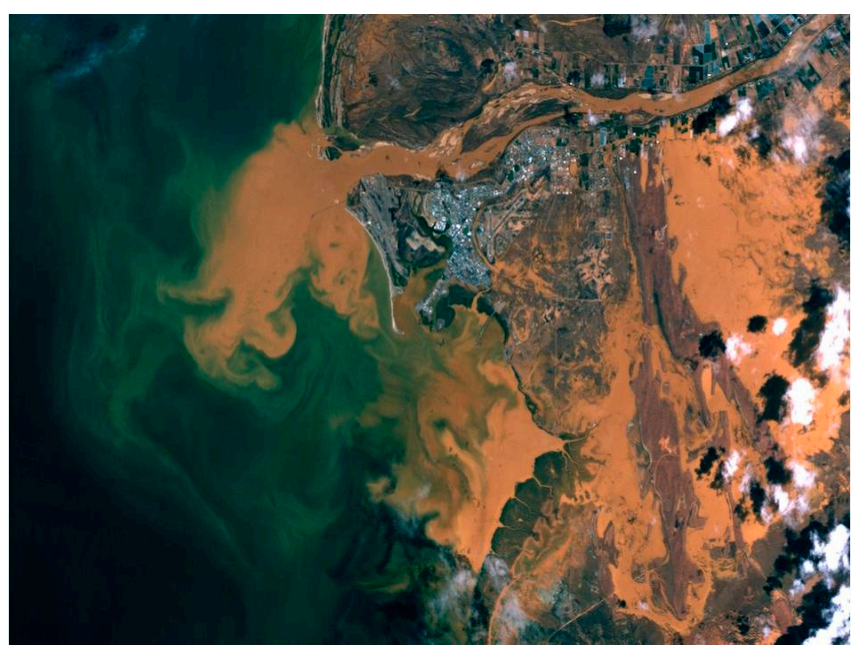

Figure 13. Gascoyne River mouth sediment plume - 10.00 am, 22 December 2010. Image processed and enhanced by Landgate, Satellite Remote Sensing Services; Erosion cell [41].

Contributing factors responsible for this massive soil loss from the Gascoyne catchment were the poor condition with reduced groundcover (perennial vegetation), a series of poor growing seasons and continuous stocking of livestock [41]. This case study provides a snapshot of perhaps the most insecure soil in Australia, a situation in the making since the days of settlement.

There is a potential pathway to soil security in this region. Innovative pastoralist-led initiatives to regenerate the landscape have had proven success in-so-far as they have been able to be applied with limited private resources [42]. However, without public policy support and significant investment, wide-scale regeneration and subsequent return to agricultural productivity will be difficult.

Climate change projections are for warmer, drier weather with more time in drought with little change in wind speeds, which will increase the susceptibility of Australian soil to wind erosion [43], and reduced, rather than enhanced soil security. In addition, extremes in rainfall (intensity and scarcity) [43] are likely which means that water erosion may also increase in the future.

\section{Triage for Soil Security}

The Australian National Soil Research, Development and Extension Strategy emphasizes the need for mapping, modeling and monitoring of soil conditions, but as important as those activities are, none of the diagnostic activities will in themselves lead to soil security. As stated in the introduction, soil security can only be achieved when all five dimensions of soil security are addressed. This requires agricultural land management practices that are matched to the functional capability of the soil, and which improve and maintain soil condition, and implies that farmers are well connected with their soil and have the knowledge and resources and public policy support to apply them.

We have demonstrated in the case studies above that when an integrated approach is used, improvements in soil security are possible e.g., the impact of conservation tillage in cropping zones, and the marked effect this has had in reducing soil erosion. However, soil degradation, and specifically soil erosion, still poses an existential threat to soil and to soil security. Soil condition monitoring provides indicators of land degradation, however it does not provide a solution. Soil security provides a positive framework for developing solutions. We contend therefore that monitoring the continued degradation 
of Australia's soil will not lead to soil security. We propose therefore, an approach to determining soil that is at risk, and prioritizing the application of treatment plans to secure that soil-i.e., "triage" for soil security.

The word "triage" is used almost exclusively in medical contexts to describe a decision system that prioritizes the allocation of scarce resources to patients. According to Iserson and Moskop [44] medical triaging is based on the satisfaction of three key conditions: a scarcity of medical resources, the assessment of needs for each patient by a triage officer based on a medical examination, and establishment of a system or plan, usually based on an algorithm or set of criteria to determine treatment and/or the priority of treatment for the patient.

The French root word, "trier", means "to sort", and was originally used to describe the sorting of agricultural products [44]. It is not unfitting therefore to think of soil in any form of degraded state and which impacts the production of agricultural products, as a patient requiring medical attention. Soil in this parlous state is insecure - the question is whether it needs minor treatment or intensive care in order to make it secure. The analogy is extended further (Table 1).

Table 1. Application of the principles of medical triage to triage for degraded soil.

\begin{tabular}{ll}
\hline Medical Triage & Triage for Soil Security \\
\hline $\begin{array}{l}\text { 1. Scarcity of medical resources. } \\
\begin{array}{l}\text { 2. Assessment of needs of each patient } \\
\text { by a triage officer based on } \\
\text { a medical examination. }\end{array}\end{array}$ & $\begin{array}{l}\text { 1. Scarcity of public and private resources to halt } \\
\text { and/or reverse soil degradation and secure soil. }\end{array}$ \\
\hline $\begin{array}{l}\text { at a determined unit level, based on expert } \\
\text { assessment and condition monitoring. }\end{array}$ \\
$\begin{array}{l}\text { 3. Establishment of a system or plan, } \\
\text { usually based on an algorithm or set of } \\
\text { criteria to determine treatment and/or } \\
\text { the priority of treatment for the patient }\end{array}$ & $\begin{array}{l}\text { security, to determine a treatment plan and to } \\
\text { prioritise the treatment of soil that is at high risk } \\
\text { of loss. The plan must meet the criteria laid out } \\
\text { by the five dimensions of soil security. }\end{array}$ \\
\hline
\end{tabular}

In order for a triage officer to make use of an established plan to treat the patient, the plan must first exist and there must be a decision to use the plan. In this context, triage planning for soil security would involve development and adoption of a national approach, utilized and implemented at State level to prioritize and determine the treatment of degraded soils in particular agricultural contexts (paraphrasing Iserson and Moskop [44]). By linking "prioritized treatment plans" with approaches to agriculture the requirements for soil security can be met by simultaneously increasing agricultural productivity and improving soil condition, supported by public policy that enables the required extension and education programs for implementation, the requirements for soil security can be met.

This triage framework would address the issues outlined above and make the best use of limited resources for supporting soil that needs "intensive care". This would include soil that is at greatest risk of wind and water erosion. In the future, how will soil erosion respond to climate changes, will land management change cope with soil erosion responses or cause a reversal and increase in soil degradation? Unless careful consideration is given to how ground cover protects the soil from wind and water erosion, the next phase of agricultural expansion in northern Australia could cause an 
increase in soil erosion that could be a large unmitigated risk for soil security. For example, cover viewed from above (fractional cover) of the soil surface is a poor representation of the protection against wind and water erosion since both processes operate laterally requiring lateral cover. A highly prioritised treatment plan for "at risk soil" would focus on agricultural and grazing strategies that increase lateral vegetation cover. However, as demonstrated above, going down into the soil itself, and applying SUE to management practices will take agriculture and soil security to the next level that is required for long term sustainability.

The development of such a plan would require a significant coordinated effort, similar to that made to develop the National Strategy. The Strategy lays the groundwork for research, development and extension that is required. The charter for its implementation could be easily widened to develop a triage system for soil security. Involving innovative agronomy and farmer groups in this process will ensure that an agricultural approach to solutions is maintained.

\section{Recommendations and Conclusions}

We conclude with two recommendations that will contribute to the future security of Australian agricultural soils. At the farm scale, we recommend the continued development and adoption of soil management-based agriculture, including diagnostic and management tools such as SUE and Vertical Rate guidelines, as a practical approach for securing soil and alleviating or reversing soil degradation, while at the same time increasing productivity. Public policy support for this approach should include a renewed focus on soil security by State Governments and full implementation of the National Soil Research Development and Extension Strategy.

At the continental scale we recommend the development of a triage approach to mitigate soil degradation, framed by the five dimensions of soil security. This will provide an early warning system for soil loss, identify soils with the highest risk, and provide focus on areas where soil is insecure. Research, development and extension activities will be needed to find ways in which agricultural management practices can reduce soil loss, benefit from soil condition improvement and deal with the associated "creeping" issues of acidification and soil carbon loss, while at the same time increasing productivity.

The National Strategy now forms part of the backdrop for a changing national agriculture policy that includes development of agriculture in northern Australia and the requirement for a competitive and sustainable agriculture sector in the future. By integrating a soil security focus into this context, Australia's soil resource will continue to provide food, fiber, water, and environmental services and the economic returns required by the Australian people.

\section{Author Contributions}

Each author contributed to preparation of various components that were combined in this paper. Andrea Koch coordinated the effort and combined the components. 


\section{Conflicts of Interest}

Andrea Koch declares no conflict of interest. Adrian Chappell declares no conflict of interest. Edward Scott and Michael Eyres are both employed by Injekta Field Systems, a soil advisory business in conservation tillage based agricultural systems and both authors do not have a conflict of interest in relation to the information provided in this paper at date of submission.

\section{References}

1. McBratney, A.B.; Field, D.J.; Koch, A. The dimensions of soil security. Geoderma 2013, 213, 203-213.

2. Koch, A.; McBratney, A.; Adams, M.; Field, D.; Hill, R.; Crawford, J.; Minasny, B.; Lal, R.; Abbott, L.; O'Donnell, A.; et al. Soil Security: Solving the Global Soil Crisis. Glob. Policy 2013, 4, 434-441.

3. Cork, S.; Eadie, L.; Mele, P.; Price, R.; Yule, D. The Relationships between Land Management Practices and Soil Condition and the Quality of Ecosystem Services Delivered from Agricultural Land in Australia; Kiri-ganai Research Pty Ltd.: Canberra, Australia, 2012.

4. Doran, J.W.; Zeiss, M.R. Soil health and sustainability: Managing the biotic component of soil quality. Appl. Soil Ecol. 2000, 15, 3-11.

5. Department of Agriculture. The National Soil Research, Development and Extension Strategy, Securing Australia's Soil, for Profitable Industries and Healthy Landscapes. Available online: daff.gov.au/natural-resources/soils (accessed on 23 February 2015).

6. Lal, R. Soil degradation by erosion. Land Degrad. Dev. 2001, 12, 519-539.

7. Australian Bureau of Statistics. 1301.0-Year Book Australia, Changing Patterns of Land Use in Australia, 1988. Available online: http://www.abs.gov.au/ausstats/abs@.nsf/featurearticlesbytitle/ 92916F88103CF060CA2569DE001F1085?OpenDocument (accessed on 25 February 2015).

8. Henzell, T. Australian Agriculture: Its History and Challenges; CSIRO Publishing: Collingwood, Australia, 2007.

9. Carey, B. Saving our soil: Soil Conservation in Queensland since the 1930s. Available online: http://www.slq.qld.gov.au/audio-video/webcasts/queensland-memory (accessed on 23 February 2015).

10. Breckwoldt, R. The Dirt Doctors a Jubilee History of the Soil Conservation Service of NSW; Soil Conservation Service of NSW: Sydney, Australia, 1988.

11. Tideman, A.F. The Struggle for Landcare in South Australia. Available online: http://www.pir.sa.gov.au/_data/assets/file/0017/151082/NRMHist_Struggle_V16.pdf (accessed on 23 February 2015).

12. D'Emden, F.H.; Llewellyn, R.S.; Burton, M.P. Adoption of conservation tillage in Australian cropping regions: An application of duration analysis. Technol. Forecast. Soc. Chang. 2006, 73, 630-647. 
13. ABS. 4627.0 - Land Management and Farming in Australia, 2012-2013. Available online: http://www.abs.gov.au/AUSSTATS/abs@.nsf/Latestproducts/4627.0Main\%20Features12012-13? opendocument \&tabname $=$ Summary\&prodno $=4627.0 \&$ issue $=2012-13 \&$ num $=\& v i e w=\quad($ accessed on 23 February 2015).

14. Safstrom, R.D.; Waddell, P.-J. Using economic, social and ecological spatial patterns to guide policy development in the Pilbara and Southern Rangelands of Western Australia. Rangel. J. 2013, 35, 231-239.

15. Australian Government White Paper on Developing Northern Australia, 2014. Available online: https://northernaustralia.dpmc.gov.au/ (accessed on 10 March 2015).

16. State of the Environment Committee. Australia State of the Environment 2011; Independent Report to the Australian Government Minister for Sustainability, Environment, Water, Population and Communities; DSEWPaC: Canberra, Australia, 2011.

17. Australian Bureau of Agricultural and Resource Economics and Sciences. Land Use and Land Management Information for Australia: Workplan of the Australian Collaborative Land Use and Management Program (ACLUMP); ABARES: Canberra, Australia, 2010.

18. National Land \& Water Resources Audit. The National Land and Water Resources Audit 2002-2008. Achievements and Challenges; National Land \& Water Resources Audit: Canberra, Australia, 2008.

19. Herbert, A. Opportunity Costs of Land Degradation Hazards in the South-West Agriculture Region; Resource Management Technical report 349; Western Australian Agriculture Authority: Perth, Australia, 2009.

20. Sanderman, J.; Farquharson, R.; Baldock, J. Soil Carbon Sequestration Potential: A Review for Australian Agriculture; Commonwealth Scientific and Industrial Research Organisation: Canberra, Australia, 2010.

21. Campbell, A. Managing Australia's Soils: A Policy Discussion Paper. http://www.clw.csiro.au/ aclep/documents/Soil-Discussion-Paper.pdf (accessed on 16 April 2015).

22. Lu, H.; Prosser, I.P.; Moran, C.J.; Gallant, J.C.; Priestley, G.; Stevenson, J.G. Predicting sheetwash and rill erosion over the Australian continent. Aust. J. Soil Res. 2003, 41, 1037-1062.

23. Loughran, R.J.; Elliott, G.L.; McFarlane, D.J.; Campbell, B.L. A survey of soil erosion in Australia using caesium-137. Aust. Geogr. Stud. 2004, 42, 221-233.

24. Chappell, A.; Hancock, G.; Viscarra Rossel, R.; Loughran, R. Spatial uncertainty of the ${ }^{137}$ Cs reference inventory for Australian soil. J. Geophys. Res. Earth Surf. 2011, 116, doi:10.1029/2010JF001942.

25. Chappell, A.; Viscarra Rossel, R.; Loughran, R. Spatial uncertainty of ${ }^{137}$ Cs-derived net (1950s-1990) soil redistribution for Australia. J. Geophys. Res. Earth Surf. 2011, doi:10.1029/2010JF001943.

26. Scott, B.J.; Eberbach, P.L.; Evans, J.; Wade, L.J.; Graham, E.H. Centre Monograph No. 1: Stubble Retention in Cropping Systems in Southern Australia: Benefits and Challenges; Clayton, E.H., Burns, H.M., Eds.; Industry \& Investment NSW: Orange, Australia, 2010.

27. Wang, X.B.; Enema, O.; Hoogmed, W.B.; Perdok, U.D.; Cai, D. Dust storm erosion and its impact on soil carbon and nitrogen losses in northern China. Catena 2006, 66, 221-227.

28. Zhang, G.S.; Chan, K.Y.; Oates, A.; Heenan, D.P.; Huang, G.B. Relationship between soil structure and runoff/soil loss after 24 years of conservation tillage. Soil Tillage Res. 2007, 92, $122-128$. 
29. Llewellyn, R.S.; D’Emden, F.H. Adoption of No-tillage Cropping Practices in Australian Grain Growing Regions; Grains Research and Development Corporation: Kingston, Australia, 2010; pp. 1-31.

30. Chappell, A.; Sanderman, J.; Thomas, M.; Read, A.; Leslie, C. The dynamics of soil redistribution and the implications for soil organic carbon accounting in agricultural south-eastern Australia. Glob. Chang. Biol. 2012, 18, 2081-2088.

31. Marx, S.K.; McGowan, H.A.; Kamber, B.S.; Knight, J.M.; Denholm, J.; Zawadzki, A. Unprecedented wind erosion and perturbation of surface geochemistry marks the Anthropocene in Australia. J. Geophys. Res. 2014, 119, 45-61.

32. Hopley. J.; Perry, E.; Clark, R.; MacEwan, R. Wind Erosion Threat and Agricultural Land Cover in the Mallee; Report for the Mallee CMA; Department of Environment and Primary Industries: Melbourne, Australia, 2013.

33. Reicosky, D.C.; Allmaras, R.R. Advances in tillage research in North American cropping systems. J. Crop. Prod. 2003, 8, 75-125.

34. Anderson, G. The Impact of Tillage Practices and Crop Residue (Stubble) Retention in the Cropping System of Western Australia; Department of Agriculture and Food: South Perth, Australia, 2009.

35. Valzano, F.; Murphy, B.; Koen, T. The Impact of Tillage on Changes in Soil Carbon Density with Special Emphasis on Australian Conditions; National Carbon Accounting System Technical Report; Australian Greenhouse Office: Canberra, Australia, 2005.

36. Chappell, A.; Webb, N.P.; Butler, H.; Strong, C.; McTainsh, G.H.; Leys, J.F.; Viscarra Rossel, R. Soil organic carbon dust emission: An omitted global source of atmospheric $\mathrm{CO}_{2}$. Glob. Chang. Biol. 2013, 19, 3238-3244.

37. Doetterl, S.; van Oost, K.; Six, J. Towards constraining the magnitude of global agricultural sediment and soil organic carbon fluxes. Earth Surf. Proc. Land. 2012, 37, 642-655.

38. Chappell, A.; Webb, N.P.; Viscarra Rossel, R.A.; Bui, E. Australian net (1950s-1990) soil organic carbon erosion: Implications for $\mathrm{CO}_{2}$ emission and land-atmosphere modelling. Biogeosciences 2014, 11, 5235-5244.

39. Leys, J.F.; Heidenrich, S.K.; Strong, C.L.; McTainsh, G.H.; Quigley, S. PM10 concentrations and mass transport during "Red Dawn"-Sydney 23 September 2009. Aeolian Res. 2011, 3, 327-342.

40. Tozer, P.; Leys, J. Dust storms - What do they really cost? Rangel. J. 2013, 35, 131-142.

41. Waddell, P.A.; Thomas, P.W.E.; Findlater, P.A. A Report on the Gascoyne River Catchment Following the 2010/11 Flood Events; Department of Agriculture and Food: South Perth, Australia, 2012.

42. Soils for Life. Restoring the Gascoyne Rangeland-Commitment, Cooperation and Hard Work. Accessible online: http://www.soilsforlife.org.au/case-studies.html (accessed on 10 March 2015).

43. CSIRO and Bureau of Meteorology. Climate Change in Australia Information for Australia's Natural Resource Management Regions: Technical Report. Accessible online: http://www.climatechangeinaustralia.gov.au/media/ccia/2.1.5/cms_page_media/168/CCIA_2015_ NRM_TechnicalReport_WEB.pdf (accessed on 16 April 2015). 
44. Iserson, K.V.; Moskop, J.C. Triage in Medicine, Part I: Concept, History, and Types. Ann. Emerg. Med. 2007, 49, 275-281.

(C) 2015 by the authors; licensee MDPI, Basel, Switzerland. This article is an open access article distributed under the terms and conditions of the Creative Commons Attribution license (http://creativecommons.org/licenses/by/4.0/). 